\title{
Didymocarpus sinoindicus (Gesneriaceae), a new species from India and China
}

\author{
Prasanna N.S. ${ }^{1 \$}$, Liu D.T. ${ }^{2 \$}$, Saryan P. ${ }^{1}$, Duan S.Z. ${ }^{3}$, Cai L. ${ }^{2,4 *}$ \& V. Gowda ${ }^{1 *}$ \\ ${ }^{1}$ Tropical Ecology and Evolution (TrEE) Lab, Department of Biological Sciences, \\ Indian institute of Science Education and Research, Bhopal - 462 066, India. \\ ${ }^{2}$ Yunnan Key Laboratory for Integrative Conservation of Plant Species with Extremely Small Populations; \\ Key Laboratory for Plant Diversity and Biogeography of East Asia, Kunming Institute of Botany, \\ Chinese Academy of Sciences, Kunming, Yunnan - 650 201, China. \\ ${ }^{3}$ Tengchong Branch of Baoshan Administration of Gaoligongshan National Nature Reserve, \\ Tengchong, Yunnan - 679 100, China. \\ ${ }^{4}$ University of Chinese Academy of Sciences, Beijing - 100 049, China. \\ *E-mails: cailei@mail.kib.ac.cn; gowdav@iiserb.ac.in \\ $\$$ Contributed equally
}

\begin{abstract}
We describe a new species of Gesneriaceae, Didymocarpus sinoindicus N.S.Prasanna, Lei Cai \& V.Gowda from India and China with detailed morphological description, diagnostic characters, illustrations, and colour photographs. The new species is morphologically similar to D. oblongus Wall. ex D.Don, D. hookeri C.B.Clarke, and D. adenocalyx W.T.Wang, but can be easily distinguished from them by its remarkable creamy-white to greenish-yellow sepals and petals and characteristic purple striations on corolla lobes.
\end{abstract}

Keywords: Kingdon-Ward, Nagaland, Northeast India, Saramati hills, Tengchong, Yunnan.

\section{Introduction}

The genus Didymocarpus Wall. (Gesneriaceae) was originally considered a large genus having different taxonomic affinities and distributed in Madagascar, Western Ghats and Southeast Asia (Burtt, 1998[“1997"]). After recircumscription of the genus based on morphological characters (Weber \& Burtt, 1998[“1997"]; Weber et al., 2000) and further supported by molecular phylogenetic data (Möller et al., 2011; Möller \& Clark, 2013), the genus now has over 100 species, distributed from the Himalayas to Malay Peninsula (Möller, 2019; Souvannakh-

Received: 04.12.2019; Revised \& Accepted: 20.03.2020

Published Online: 11.05 .2020 oummane et. al., 2019; Yang et al., 2019; Adhikari \& Möller, this issue). China harbours the highest diversity of this genus with 34 species and five varieties, followed by India with 23 species and two varieties (Möller et al., 2016, 2017; Möller, 2019; Wen et al., 2019; Yang et al., 2019; Lahiri et al., 2020). Several new taxa have been discovered and rediscovered from both China and India recently (Cai et al., 2016; Joe et al., 2016; Yang et al., 2019; Prasanna \& Gowda, 2020). In China, Didymocarpus is mainly distributed in the South and Southwest of the country (Wang et al., 1998; Cai et al., 2016), whereas in India, the Sikkim-Himalayan region has the highest diversity followed by the Indo-Burma region (Sinha \& Datta, 2016; Pandey et al., this issue; Prasanna \& Gowda, 2020).

During our field expeditions in Northeast India in 2018, we (NSP, PS, and VG) came across a morphologically distinct, unidentified species of Gesneriaceae. By coincidence, similar specimens were collected by DTL, SZD, and LC from Mt. Gaoligong of western Yunnan, China in 2019. Our field collections included herbarium vouchers, spirit samples, and molecular grade leaf tissues in silica. We took detailed morphological measurements from both fresh samples and preserved flowers using a ruler and digital calipers, and all collections are deposited at BHPL, ASSAM and KUN. Based on 
the presence of two fertile stamens, a disc-like stigma, an orthocarpic ovary, and a bivalve capsule which dehisces loculicidally, we attributed it to the genus Didymocarpus (Weber \& Burtt, 1998[“1997”]). In order to identify the specimens, we extensively examined Didymocarpus protologues, monographs and regional revisions (Kanjilal et al., 1939; Wang et al., 1990, 1998; Grierson \& Long, 2001; Sinha \& Datta, 2016; Roy, 2017). We also consulted herbarium collections including type specimens from ARUN, ASSAM, BHPL, BM, BSHC, CAL, E, HITBC, IBK, K, KUN, PE, digital images from C, M, TCD, and online databases (Global Plants: https:// plants.jstor.org/; Muséum national d'Histoire naturelle: https://science.mnhn.fr/; Smithsonian Institution: https://www.si.edu/; The Linnean Collections: http://linnean-online.org/; Chinese Virtual Herbarium: http://www.cvh.ac.cn/). After comparisons with taxa having similar morphological characters and from related geographic ranges, we came to the conclusion that the specimens being studied represented a new species of Didymocarpus. We describe it here as Didymocarpus sinoindicus and compare it with three morphologically similar species D. oblongus Wall. ex D.Don, D. hookeri C.B.Clarke, and D. adenocalyx W.T.Wang (Table 1), and illustrate it with photographs and line drawings. We evaluated the conservation status for the species according to the International Union for Conservation of Nature guidelines (IUCN, 2019).

Didymocarpus sinoindicus N.S.Prasanna, Lei Cai \& V.Gowda, sp. nov.

Figs. $1,2 \& 3$

Didymocarpus sinoindicus is morphologically similar to D. oblongus Wall. ex D.Don, but differs from it in having longer petioles $(1.5-6.5 \mathrm{~cm}$ vs. $0.2-1.5 \mathrm{~cm}$ long), bicrenate or serrate leaf margins ( $v$ s. serrate to doubly serrate), and creamy-white to greenish-yellow ( $v s$. purplish) corolla tube. It differs from $D$. hookeri C.B.Clarke in having shorter stems $(2-8 \mathrm{~cm} v s .4-17 \mathrm{~cm}$ long), and glabrous ( $v$ s. pubescent) corolla tubes. The new species differs from $D$. adenocalyx W.T.Wang in having glandular pedicels and calyces ( $v s$. eglandular), and shorter corolla tubes $(0.7-1 \mathrm{~cm}$ vs. c. $1.4 \mathrm{~cm}$ long).
Type: INDIA, Nagaland, Kiphire district, Mount Saramati, N 25 45'11', E 9459'26", 2580 m, 29.08.2018, Preeti Saryan VG2018NL3679 (holo BHPL!; iso ASSAM!).

Perennial, lithophytic herbs. 6-15 cm tall. Dry season stem inconspicuous, juvenile leaves distinct, blades with much denser indumentum than when mature. Rainy season stem dark purple, erect, 2-8 $\times 0.2 \mathrm{~cm}$, terete, densely puberulent with multicellular eglandular hairs, densely covered with globular golden pigment glands. Leaves 2-3 pairs, opposite and anisophyllous, decussate, whorled at the top of the stem; petioles terete, $1.5-6.5 \mathrm{~cm}$ long, eglandular pubescent and pigmented as on the stem; lamina ovate to oblong or falcate oval, 4-20 × 2$10.5 \mathrm{~cm}$, base cuneate or oblique, occasionally rounded, margins bicrenate or serrate; apex obtuse to acute; adaxial surface dark green, pubescent with multicellular eglandular hairs interspersed with globular golden pigment glands; abaxial surface light green, sparsely eglandular pubescent along the veins, glabrous otherwise, sparsely covered with pigment glands; midrib with 6-10 lateral veins on each side, depressed adaxially, raised abaxially. Inflorescences 1-4, pair-flowered cymes, 6-25flowered, pedunculate, axillary towards the top of the stem or terminal; peduncle terete, $2-5 \mathrm{~cm}$ long, light green, pubescent with multicellular hairs, pigment glands present, glands dense between bracteoles and the peduncle; paired bracteoles present at each dichotomous fork; primary bracteoles (at first inflorescence fork) 2, cupular, ovate to orbicular, $0.6-1.2 \times 0.6-1.0 \mathrm{~cm}$, opposite, connate at base, light green, margins entire or sometimes crenate, glabrous, rarely pubescent towards margins, ventral surface sparsely glandular, veins visible when dried; secondary bracteoles (at subsequent inflorescence fork) cupular to navicular, ovate to suborbicular, c. $2 \times 6 \mathrm{~mm}$, connate at base, greenish-white, ventral surface sparsely glandular; pedicels $0.5-1 \mathrm{~cm}$ long, sparsely covered with gland tipped multicellular hairs, pigment glands present. Calyx campanulate, 4-6 mm long, creamy-white to greenish-yellow, basally connate, 5-lobed, to $c$. $1 / 5$ of the length; lobes ovate to ovate-triangle, 


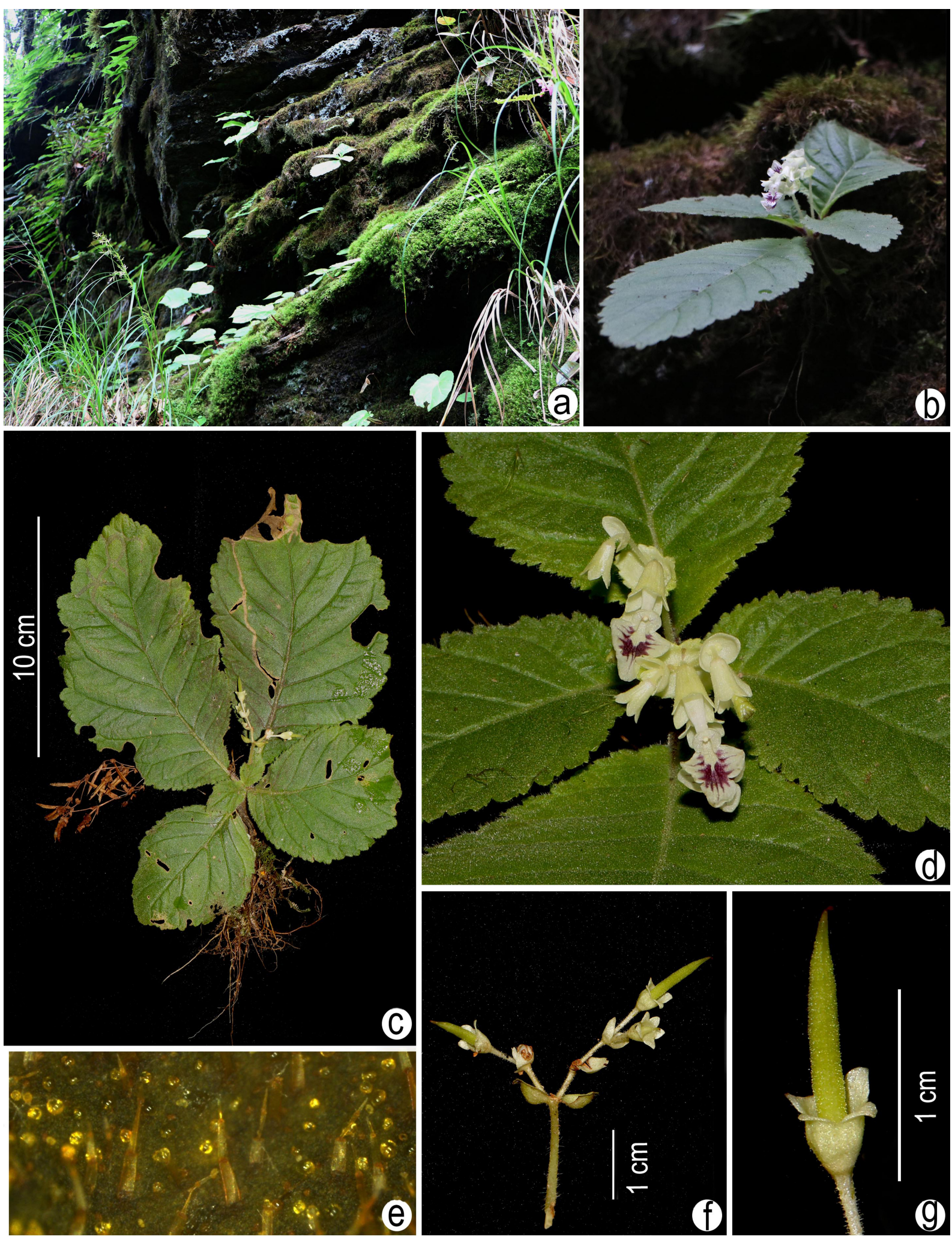

Fig. 1. Didymocarpus sinoindicus N.S.Prasanna, Lei Cai \& V.Gowda in India: a. Habitat; b. Habit; c. Whole plant with inflorescence and infructescence; d. Inflorescence; e. Glands on the abaxial surface of leaves; f. Cyme with fruits; g. Young fruit (photos by Preeti Saryan). 

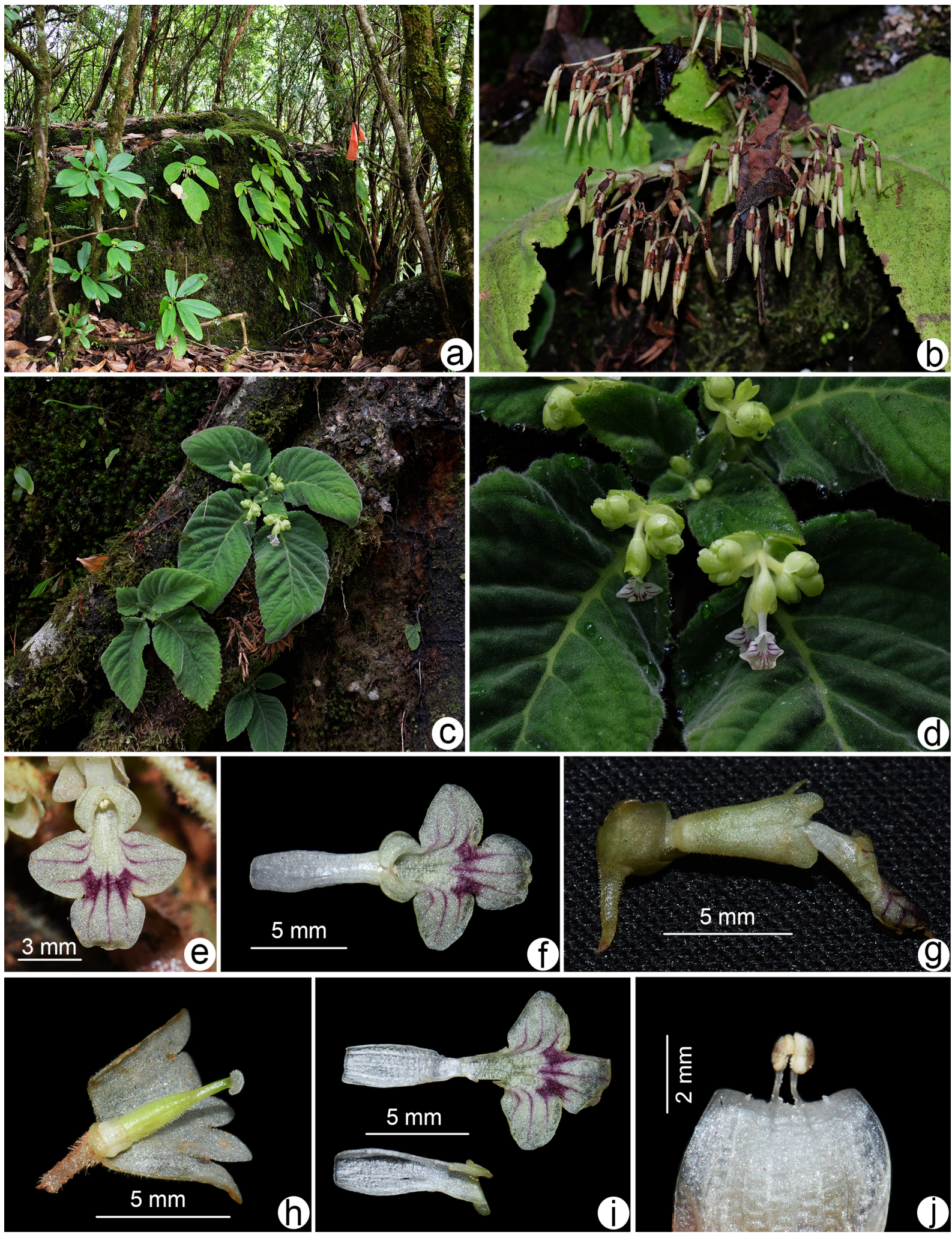

Fig. 2. Didymocarpus sinoindicus N.S.Prasanna, Lei Cai \& V.Gowda in China: a. Habitat; b. Fruits; c. Plants with flowers and old fruits; d. Inflorescence and adaxial leaf surface; e. Mouth of a flower; $\mathbf{f}$. Front view of corolla; $\mathbf{g}$. Lateral view of flower showing calyx and bracts; h. Pistil with calyx and disc; i. Opened corolla showing internal structure; j. Stamens and staminodes (photos by Lei Cai \& De-Tuan Liu). 


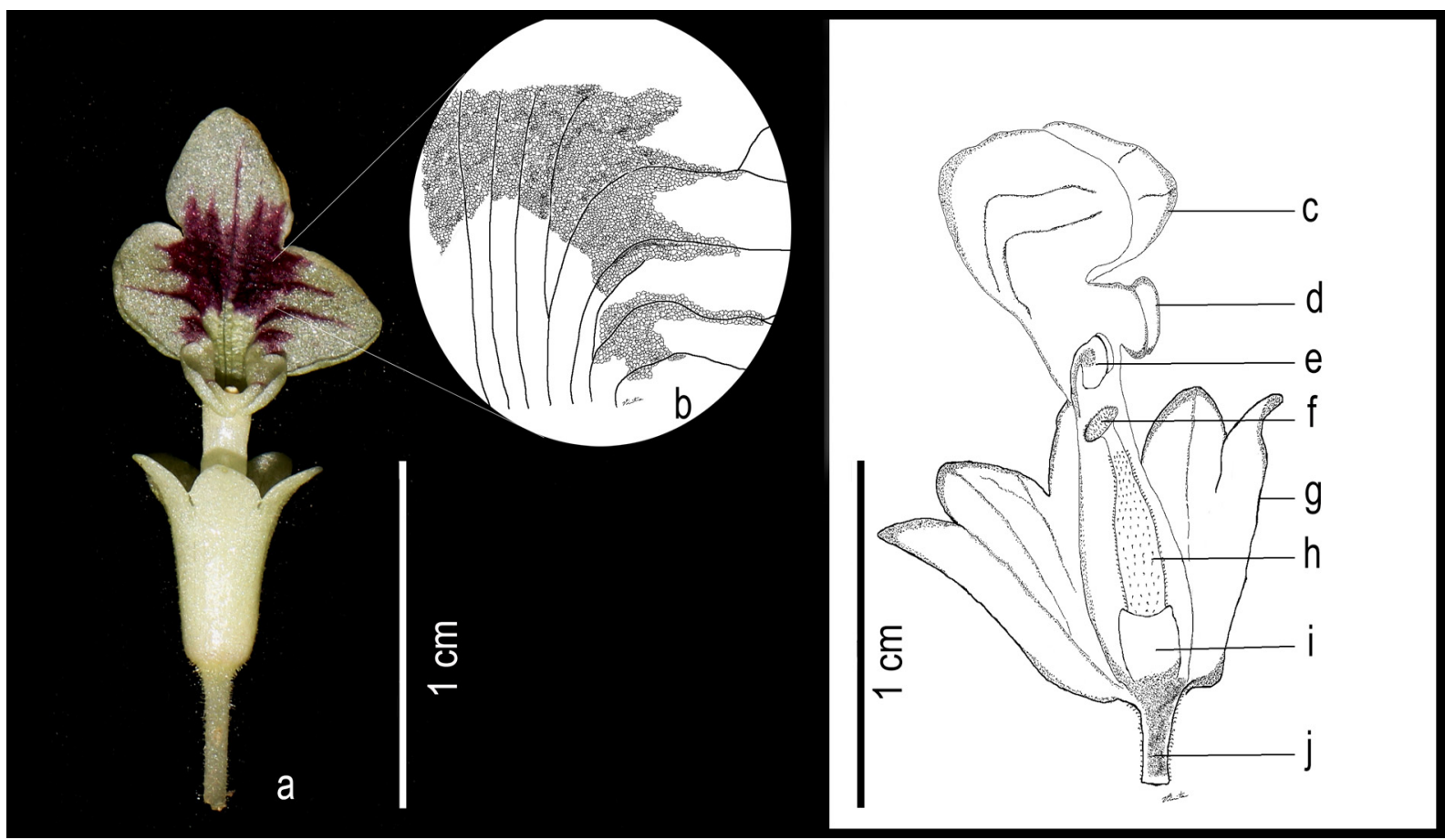

Fig. 3. Didymocarpus sinoindicus N.S.Prasanna, Lei Cai \& V.Gowda: a. Flower; b. Blotch at the junction of the three lower lobes; c. Lower lobes; d. Upper lobes; e. Androecium; f. Stigma; g. Calyx; h. Ovary; i. Disc; j. Pedicel (photos by Preeti Saryan; illustration by Vinita Gowda).

Table 1. Comparison of morphological characters of D. sinoindicus, D. adenocalyx, D. hookeri and D. oblongus

\begin{tabular}{|c|c|c|c|c|}
\hline Characters & $\begin{array}{l}\text { D. sinoindicus } \\
\text { N.S.Prasanna, Lei Cai } \\
\text { \& V.Gowda }\end{array}$ & $\begin{array}{l}\text { D. adenocalyx } \\
\text { W.T.Wang }\end{array}$ & $\begin{array}{l}\text { D. hookeri } \\
\text { C.B.Clarke }{ }^{\star \star}\end{array}$ & $\begin{array}{l}\text { D. oblongus Wall. } \\
\text { ex D.Don }\end{array}$ \\
\hline Stem & $2-8 \mathrm{~cm}$ long & c. $20 \mathrm{~cm}$ long & 4-17 cm long & $2.5-17 \mathrm{~cm}$ long \\
\hline Lamina & $\begin{array}{l}4-20 \times 2-10.5 \mathrm{~cm}, \\
\text { bicrenate or serrate, } \\
\text { Pigment glands present }\end{array}$ & $\begin{array}{l}1.8-4.2 \times 1.5-2.4 \mathrm{~cm}, \\
\text { denticulate, pigment } \\
\text { glands absent }\end{array}$ & $\begin{array}{l}4-17 \times 3-7 \mathrm{~cm}, \\
\text { crenate to serrate, } \\
\text { pigment glands } \\
\text { present }\end{array}$ & $\begin{array}{l}1.5-12.5 \times 1.2-4.5 \mathrm{~cm} \text {, } \\
\text { serrate to } \\
\text { doublyserrate, pigment } \\
\text { glands present }\end{array}$ \\
\hline Petioles & $1.5-6.5 \mathrm{~cm}$ long & $0.4-1.1 \mathrm{~cm}$ long & 4-7 cm long & $0.2-1.5 \mathrm{~cm}$ long \\
\hline Peduncles & Glandular & Eglandular & Glandular & Glandular \\
\hline Calyx tube & $\begin{array}{l}\text { 3.5-4 mm long, } \\
\text { glandular }\end{array}$ & $\begin{array}{l}\text { c. } 2.6 \mathrm{~mm} \text { long, } \\
\text { eglandular }\end{array}$ & $\begin{array}{l}\text { 2-3 mm long, } \\
\text { eglandular }\end{array}$ & $\begin{array}{l}\text { 2-3.5 mm long, } \\
\text { eglandular }\end{array}$ \\
\hline Corolla tube & $\begin{array}{l}0.7-1 \mathrm{~cm} \text { long, glabrous, } \\
\text { creamy-white to } \\
\text { greenish-yellow }\end{array}$ & $\begin{array}{l}\text { c. } 1.4 \mathrm{~cm} \text { long, } \\
\text { glabrous, } \\
\text { reddish purple }\end{array}$ & $\begin{array}{l}2-2.5 \mathrm{~cm} \text { long, } \\
\text { pubescent, } \\
\text { yellowish white }\end{array}$ & $\begin{array}{l}0.8-1.4 \mathrm{~cm} \text { long, } \\
\text { glabrous, purplish }\end{array}$ \\
\hline Staminal filament & $0.8-1.5 \mathrm{~mm}$ long & c. $4 \mathrm{~mm}$ long & $5.5-7.2 \mathrm{~mm}$ long & c. $5 \mathrm{~mm}$ long \\
\hline Staminodes & $\begin{array}{l}\text { Inconspicuous or } \\
\text { minimal, c. } 0.15 \mathrm{~mm} \\
\text { long }\end{array}$ & $1.2-1.5 \mathrm{~mm}$ long & c. $2 \mathrm{~mm}$ long & Inconspicuous \\
\hline
\end{tabular}

${ }^{\star}$ Based on Wang (1986), Wang et al. (1990, 1998); ${ }^{\star \star}$ Clarke (1874), Sinha \& Datta (2016), Roy (2017); ${ }^{\star \star \star}$ Don (1825), Grierson \& Long (2001), Roy (2017). 
equal, 1-1.8 × 1-1.5 mm, covered with peltate pigment glands outside, glabrous inside. Corolla bilabiate creamy-white to greenish-yellow with purple striations on the limbs; tube 7-10 $\times 1.5-3$ $\mathrm{mm}$, broader at the base, narrow towards lobes, glabrous; corolla limb bilabiate, glabrous, eglandular, upper lip 2-lobed, lobes suborbicular, $1.5-2 \times 1 \mathrm{~mm}$, held at right angles to the lower lobes, creamy white, lower lip 3-lobed, lobes semiorbicular to ovate, 3-4 × 3-4 mm, creamywhite with purple blotch at the junction of the three lower lobes, purple striations extending from the base of each lobe towards the tip. Stamens 2, adnate to corolla, 5-6 $\mathrm{mm}$ from the base, inserted above the midpoint of the tube; filaments $0.8-1.5 \mathrm{~mm}$ long, glabrous; anthers c. $0.8 \mathrm{~mm}$ long, glabrous, dorsifixed, coherent by adaxial surfaces, exserted. Staminodes 2, inconspicuous or minimal, c. 0.15 $\mathrm{mm}$ long, adnate to corolla 5-6 $\mathrm{mm}$ from base. Disc tubular with undulating upper margins, $1-1.2 \mathrm{~mm}$ long, glabrous, persistent. Pistils 5.5-6.5 mm long. Ovary cylindrical, 3-3.5 mm long, stipe absent, covered with peltate pigment glands; style c. $2 \mathrm{~mm}$ long, glabrous; stigma peltate, pubescent. Capsules linear, bivalved, dehisce loculicidally, c. 1.4-1.6 × $0.15 \mathrm{~cm}$, covered with glands; seeds unknown.

Flowering \& fruiting: Flowering from July to September in India and April to August in China and fruiting from August to November in both India and China.

Habitat: Didymocarpus sinoindicus grows on moss covered, rocky cliffs in heavily shaded forests at an altitude of 2200 to $2600 \mathrm{~m}$. In India, it occurs along with Rhododendrons in the temperate forests. In China, it occurs in evergreen broad-leaved forest along with Rhododendron delavayi Franch., $R$. ovatum (Lindl.) Planch. ex Maxim., Vaccinium sp. and Gaultheria griffithiana Wight (Ericaceae), Viburnum cylindricum Buch.-Ham. ex D.Don (Caprifoliaceae), Myrsine semiserrata Wall. (Myrsinaceae), Rubus lineatus Reinw. (Rosaceae) and a few other species of Theaceae and Fagaceae.

Distribution: Currently, it is known from only two locations in India and one location in China, all of them bordering Myanmar. In India, the type locality is near the base camp of Mount Saramati in Kiphire district in the northeastern state of Nagaland. There is a historical collection site on the nearby Japvo ridge in Nagaland. In China, it is found in Danzha Village of Tengchong in Yunnan Province. It is likely to be present in the high elevation areas of Sagaing and Kachin states of northern Myanmar due to its similar habitat and proximity to the type locality.

Etymology: The specific epithet 'sinoindicus' refers to the two collection localities from where the species has been collected and is known until now (China and India). It also acknowledges the serendipitous, simultaneous description of this species from two different research groups from India and China which happened to arrive at the same conclusions.

Specimens examined: CHINA, Yunnan, Tengchong City, Houqiao Town, Danzha Village, Langyashan, $25^{\circ} 30^{\prime} \mathrm{N}, 98^{\circ} 17^{\prime} \mathrm{E}$, elev. $2528 \mathrm{~m}$, 09.10.2019, D.T. Liu et al. CL19005 (KUN). INDIA, Nagaland, Naga hills, Japvo ridge, 7200 ft (2194 m), 11.11.1949, F. Kingdon-Ward 19018 (BM [BM011026036, BM011026038], E [E00627990], NYBG [NYBG02652121 digital image]).

Conservation status: We found only a small population of five mature individuals at Mt. Saramati, Nagaland, India. This is a community protected area with very little anthropogenic disturbance. The current status of the population at the Japvo ridge locality, $100 \mathrm{~km}$ distant from the Mt. Saramati locality, is unknown. The collection from China is limited to only one location. Although there are suitable habitats in between the currently known locations, there is lack of systematic survey for a conservation assessment. Thus we categorize it as data deficient (DD) following the IUCN guidelines (IUCN, 2019).

Notes: In 1949, the English botanist Kingdon-Ward collected a few specimens of Didymocarpus from the Japvo ridge of Nagaland, India which resembles 
D. sinoindicus (F. Kingdon-Ward 19018). He had identified the specimens as Didymocarpus species based on vegetative structures and fruits, but failed to assign a species name due to lack of flowers.

This manuscript is an outcome of an unexpected collaborative work between two independent research groups from India (NSP, PS and VG) and China (DTL, SZD and LC). 69 years after Kingdon-Ward's collection, the Indian group collected specimens in 2018 and the Chinese group in 2019. Coincidentally, both manuscripts were submitted for publication in the special issue of Rheedea on Gesneriaceae. Both the groups had described their respective new species using specific epithet that reflected the respective type localities (Saramati hills in India and Tengchong in China). Incidentally, the reviewers and the editor discovered the similarities in the two species and suggested for further study by the authors which has resulted in this collaborative work, and a collaborative description of $D$. sinoindicus. This study therefore illustrates the need for more collaborative floristic studies between India and China which will give us a better insight in our shared biodiversity, allow us to implement better conservation practices, and reduce taxonomic confusions.

\section{Acknowledgements}

NSP, PS and VG would like to thank Science and Engineering Research Board (SERB ECR/2017/ 001073) and DBT-NER (BT/PR24525/NER/95/ 754/2017) for research funds, IISER Bhopal for Infrastructure support; MHRD (GATE Ecology \& Evolution) for fellowship to NSP; Council for Science and Industrial Research (CSIR) for fellowship to PS; Sibbald Trust (RBGE, UK) and Nellie D. Sleeth fellowship of Gesneriad Society, USA, for grants to NSP for fieldwork and herbarium consultation. NSP, PS and VG acknowledge the State Forest Department of Nagaland and Thanamir Village Biodiversity Committee for the research permit; ARUN, ASSAM, BHPL, BM, BSHC, C, CAL, E, K, M, P, and TCD for herbarium consultation. Study in
China was financially jointly supported by the Biodiversity Survey and Assessment Project of the Ministry of Ecology and Environment, China (2019HJ2096001006), the Science \& Technology Basic Resources Investigation Program of China (grant no. 2017FY100100) and the STS Program of the Chinese Academy of Sciences (grant no. KFJ3 W-No1). We are grateful to Dr. Yong-Peng Ma and Mr. Yu-Hang Chang for help during the fieldwork in China. We are grateful to Dr. K.N. Gandhi (Harvard University, USA) for nomenclatural help. We thank Dr. Michael Möller and Prof. Santhosh Nampy for the invitation to write this manuscript. Finally, we would like to thank the editor and the anonymous reviewers for their critical comments that have helped to improve this study, and for inspiring this collaborative work.

\section{Literature Cited}

ADHIKARI B. \& M. MÖLLER 2020. Didymocarpus nepalensis (Gesneriaceae), a new species from Eastern Nepal. Rheedea this issue. https://dx.doi.org/10.22244/ rheedea.2020.30.01.06

BURTT B.L. 1998[“1997”]. Taxonomic history of Didymocarpus and Henckelia (Gesneriaceae). Beiträge zur Biologie der Pflanzen 70(2 \& 3): 365-375.

CAI L., CAI J. \& Y.M. SHUI 2016. Didymocarpus anningensis (Gesneriaceae), a new species from Yunnan, China. Phytotaxa 255: 292-296. http://dx.doi.org/10.11646/ phytotaxa.255.3.12

CLARKE C.B. 1874. Commelynaceae et Cyrtandraceae Bengalenses. Thacker, Spink \& \& Co., Calcutta. p. 84.

DON D. 1825. Prodromus Florae Nepalensis. Gale Press, London. p. 123.

GRIERSON A.J. \& D.G. LONG 2001. Flora of Bhutan, including a record of plants from Sikkim and Darjeeling. Volume 2(3). Royal Botanic Garden, Edinburgh. pp. 1308-1315.

IUCN 2019. Guidelines for using the IUCN red list categories and criteria. Version 14. Prepared by the Standards and Petitions Subcommittee. Available at: https://nc.iucnredlist.org/redlist/content/ attachment_files/RedListGuidelines.pdf (Accessed on 15.11.2019)

JOE A., HAREESH V.S., PRASHOB P. \& M. SABU 2016. Didymocarpus moellerii (Gesneriaceae): a new species from Northeastern India. Phytotaxa 266: 57-60. http:// dx.doi.org/10.11646/phytotaxa.266.1.10 
KANJILAL U.N., DAS A., KANJILAL P.C. \& R.N. DE 1939. Flora of Assam. Volume 3. Government of Assam, India. pp. 387-400.

LAHIRI S., DASH S.S., DAS M. \& B.K. SINHA 2020. Didymocarpus bhutanicus W.T.Wang (Gesneriaceae): a new addition to the herbs of India. Journal of Threatened Taxa 2(4): 15514-15517. https://doi.org/10.11609/ jott.5697.12.4.15514-15517

MÖLLER M. 2019. Species discovery in time: An example from Gesneriaceae in China. Guangxi Sciences 26: 1-16. https://doi.org/10.13656/j.cnki.gxkx.20190307.002

MÖLLER M. \& J.L. CLARK 2013. The state of molecular studies in the family Gesneriaceae: a review. Selbyana 31(2): 95-125.

MÖLLER M., FORREST A., WEI Y.G. \& A. WEBER 2011. A molecular phylogenetic assessment of the advanced Asiatic and Malesian didymocarpoid Gesneriaceae with focus on non-monophyletic and monotypic genera. Plant Systematics and Evolution 292: 223-248. https://doi.org/10.1007/s00606-010-0413-z

MÖLLER M., WEI Y.G., WEN F., CLARK J.L. \& A. WEBER 2016. You win some you lose some: updated generic delineations and classification of Gesneriaceaeimplications for the family in China. Guihaia 36: 4460. https://doi.org/10.11931/guihaia.gxzw201512015

MÖLLER M., NAMPY S., JANEESHA A.P. \& A. WEBER 2017. The Gesneriaceae of India: consequences of updated generic concepts and new family classification. Rheedea 27: 23-41. https://dx.doi.org/10.22244/ rheedea.2017.27.1.5

PANDEY S., KANTHRAJ A.S., RANA T.S. \& K.N. NAIR 2020. Notes on a new geographic record, rediscovery and lectotypification of some Indian Didymocarpus (Gesneriaceae). Rheedea this issue. https://dx.doi.org/ 10.22244/rheedea.2020.30.01.11

PRASANNA N.S. \& V. GOWDA 2020. Rediscovery of four narrow endemic Didymocarpus species (Gesneriaceae) from Mizoram, India, with amended species descriptions and lectotypifications. PhytoKeys (in press).

ROY S. 2017. Taxonomic studies of the family Gesneriaceae of Indian part of Eastern Himalaya. Ph.D. Thesis, University of Kalyani, West Bengal, India.

SINHA B.K. \& S. DATTA 2016. Taxonomic account on the family Gesneriaceae in Northeast India. Nelumbo 58: 1-43. https://doi.org/10.20324/nelumbo/v58/2016/ 105932

SOUVANNAKHOUMMANE, K., SOULADETH P. TAGANE S. \& C.J. YANG 2019. Flora of Nam Kading National Protected Area VI: Didymocarpus middletonii (Gesneriaceae), a new species from limestone. Edinburgh Journal of Botany 76(1): 45-54. https://doi.org/10.1017/ S0960428618000264

WANG W.T., PAN K.Y. \& Z.Y. LI 1990. Gesneriaceae. In: WANG W.T. (ed.), Flora Reipublicae Popularis Sinicae. Volume 69. Science Press, Beijing. pp. 420-451.

WANG W.T., PAN K.Y. \& Z.Y. LI 1998. Gesneriaceae. In: WU, Z.Y. \& P.H. RAVEN (eds.) Flora of China. Volume 18. Science Press, Beijing and Missouri Botanical Garden Press, St. Louis. pp. 349-358.

WEBER A. \& B.L. BURTT 1998[“1997”]. Remodelling of Didymocarpus and associated genera (Gesneriaceae). Beiträge zur Biologie der Pflanzen 70 (2 \& 3): 293-363.

WEBER A., BURTT B.L. \& E. VITEK 2000. Materials for a revision of Didymocarpus (Gesneriaceae). Annalen des Naturhistorischen Museums in Wien. Serie B für Botanik und Zoologie 102 B: 441-475.

WEN F., LI S., XIN Z.B., FU L.F., HONG X., CAI L., QIN J.Q., PAN B., PAN F.Z. \& Y.G. WEI 2019. The updated plant list of Gesneriaceae in China under the new Chinese naming rules. Guangxi Sciences 26(1): 3763. https://doi.org/10.13656/j.cnki.gxkx.20190225.002

YANG B., DING H.B., FU K.C., YUAN Y.K., YANG H.Y., LI J.W., ZHANG L.X. \& Y.H. TAN 2019. Four new species of Gesneriaceae from Yunnan, Southwest China. PhytoKeys 130: 183-203. https://doi.org/ 10.3897/phytokeys.130.34001 